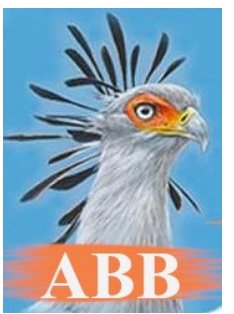

\author{
Afrotropical Bird Biology \\ Journal of the Natural History of African Birds
}

Volume 1, Issue 1

\title{
Who stole my nest? Weaver nests used as nest lining
}

\author{
Dieter Oschadleus \\ Department of Biological Sciences, University of Cape Town, Rondebosch, 7701, South Africa \\ e-mail: doschadleus@gmail.com
}

\begin{abstract}
Birds stealing nest material from a neighbour's nest is well known, but stealing entire nests is less well known. There are nine records of three waterbird species and five raptor species taking nests of four weaver species. Three records were from KwaZulu-Natal in South Africa, and the rest from elsewhere in Africa. Weaver nests included green nests, but most were old nests, and at least one occupied nest (with eggs). Weaver nests were probably taken as a convenient source of plant material, rather than for any specific benefit.
\end{abstract}

Keywords: waterbirds, raptors, weaver bird, nest material, stealing nests

Received: 5 March 2021; Accepted: 10 May 2021

\section{Introduction}

Many birds build nests and the main purpose of these nests is to protect their eggs and young (Hansell 2000). Nest building may be energetically costly, and one strategy to slightly reduce these costs could be to steal nest material from a neighbour's nest rather than collect material from further away. Stealing nest material has been recorded in penguins (Moreno et al. 1995), oropendolas, swallows and weavers, amongst others (Mainwaring and Hartley 2013, Hansell 2000). A more extreme step is to take the entire nest of another bird to incorporate in their own nest, either into the main structure or as nest lining. This study reports published records of raptors and waterbirds taking closed nests of weaverbirds, having searched bird club newsletters, peer reviewed papers, and ornithological books.

Nine records involved three waterbird species and five raptor species. (Table 1). Nests of the Southern Red Bishop Euplectes orix, Village Weaver Ploceus cucullatus, Southern Masked Weaver P. velatus, and Red-billed Quelea Quelea quelea were used. Three records were from KwaZulu-Natal, and the rest from sites as far south as the Eastern Cape, north to East Africa. No records from West or central Africa were found. Each record is discussed under the species which took the nest.

Table 1. Records of waterbirds and raptors taking complete weaver nests to incorporate in their own nests.

\begin{tabular}{|c|c|c|c|c|c|}
\hline Record & $\begin{array}{l}\text { Species taking } \\
\text { weaver nest }\end{array}$ & $\begin{array}{l}\text { Weaver spe- } \\
\text { cies }\end{array}$ & $\begin{array}{l}\text { Notes on weaver } \\
\text { nest }\end{array}$ & Locality & Reference \\
\hline 1 & Hamerkop & $\begin{array}{l}\text { Southern Red } \\
\text { Bishop }\end{array}$ & $\begin{array}{l}\text { Reeds with bishop } \\
\text { nests taken }\end{array}$ & $\begin{array}{l}\text { Eastern Cape, South } \\
\text { Africa }\end{array}$ & Davenport (1956) \\
\hline 2 & $\begin{array}{l}\text { Saddle-billed } \\
\text { Stork }\end{array}$ & Weaver & Weaver's nest taken & $\begin{array}{l}\text { Entebbe Botanical Gar- } \\
\text { dens, Uganda }\end{array}$ & Cornish (2014) \\
\hline 3 & $\begin{array}{l}\text { Woolly-necked } \\
\text { Stork }\end{array}$ & $\begin{array}{l}\text { Possibly } \\
\text { Village Weav- } \\
\text { er }\end{array}$ & $\begin{array}{l}\text { Several abandoned } \\
\text { weaver nests }\end{array}$ & $\begin{array}{l}\text { Umtentweni, KwaZulu- } \\
\text { Natal, South Africa }\end{array}$ & Millward (2009) \\
\hline 4 & Palm-nut Vulture & Weaver & Green weaver nest & $\begin{array}{l}\text { Mtunzini, KwaZulu- } \\
\text { Natal, South Africa }\end{array}$ & Harris et al. (1993) \\
\hline 5 & Yellow-billed Kite & $\begin{array}{l}\text { Probably } \\
\text { Southern } \\
\text { Masked } \\
\text { Weaver }\end{array}$ & $\begin{array}{l}\text { Kite chick on rem- } \\
\text { nants of a weaver's } \\
\text { nest }\end{array}$ & $\begin{array}{l}\text { Mkuzi Game Reserve, } \\
\text { KwaZulu-Natal, South } \\
\text { Africa }\end{array}$ & Gush (1963), Gush (1993) \\
\hline 6 & Crowned Eagle & $\begin{array}{l}\text { Village Weav- } \\
\text { er }\end{array}$ & $\begin{array}{l}\text { Some weaver's } \\
\text { nests, in two sea- } \\
\text { sons }\end{array}$ & $\begin{array}{l}\text { Agristar, near White } \\
\text { River, Mpumalanga, } \\
\text { South Africa }\end{array}$ & $\begin{array}{l}\text { Batchelor (2020), Batch- } \\
\text { elor }(2021)\end{array}$ \\
\hline 7 & African Fish Eagle & Weaver & $\begin{array}{l}\text { Several globular } \\
\text { nests of weaver birds }\end{array}$ & $\begin{array}{l}\text { Bangwe headland, Tan- } \\
\text { zania }\end{array}$ & $\begin{array}{l}\text { Bangs and Loveridge } \\
(1933)\end{array}$ \\
\hline 8 & African Fish Eagle & Weaver & $\begin{array}{l}\text { Very often padded } \\
\text { with weaver birds' } \\
\text { nests }\end{array}$ & East Africa & Brown (1980) \\
\hline 9 & $\begin{array}{l}\text { Eastern Chanting } \\
\text { Goshawk }\end{array}$ & $\begin{array}{l}\text { Red-billed } \\
\text { Quelea }\end{array}$ & $\begin{array}{l}\text { Unfinished grass } \\
\text { nest }\end{array}$ & $\begin{array}{l}\text { Tsavo National Park, } \\
\text { Kenya }\end{array}$ & $\begin{array}{l}\text { Smeenk and Smeenk- } \\
\text { Enserink (1975) }\end{array}$ \\
\hline
\end{tabular}


Hamerkop Scopus umbretta

A Hamerkop used reeds as nest material, including some reeds with nests of Southern Red Bishops attached (Davenport 1956). No locality was given, but presumably near Grahamstown (Makhanda) in the Eastern Cape, the observation being published in the journal of St Andrew's College Natural History Society, Grahamstown.

Saddle-billed Stork Ephippiorhynchus senegalensis

A Saddle-billed Stork in the Entebbe Botanical Gardens was seen carrying a weaver's nest as nesting material (Cornish 2014).

\section{Woolly-necked Stork Ciconia episcopus}

A breeding Woolly-necked Stork pair in Umtentweni, KwaZulu-Natal lined their nest with abandoned weaver nests (Millward 2009). The weaver nests are visible in the storks' nest in several photos, and one photo shows a stork delivering an old weaver nest. The rough nests appear to be those of Village Weavers rather than the smaller, neater nests of Eastern Golden Weavers $P$. subaureus.

\section{Palm-nut Vulture Gypohierax angolensis}

Harris et al. (1993) recorded a Palm-nut Vulture with a green weaver nest in its talons to use as nest lining for its own nest, in the Mtunzini area, KwaZulu-Natal, South Africa. The weaver colony (species not identified, most likely the nest of a Village Weaver or Eastern Golden Weaver) was probably not in direct association, but not too far away from the vulture nest (Oschadleus 2016). Harris et al. (1994) reported more details on this vulture nest, but did not mention the weaver nest again.

\section{Yellow-billed Kite Milvus aegyptius}

In Mkuzi Game Reserve, KwaZulu-Natal, South Africa, a Yellow-billed Kite nest contained the remnants of a weaver's nest as well as several pieces of hyaena faeces at the edge of the nest and around the young bird (Gush 1963, Gush 1993). The weaver nest was most probably that of a Southern Masked Weaver as Gush $(1963,1993)$ noted six kite nests (as well as some vulture and crow nests) that all had Southern Masked Weaver colonies in association. The nest was probably collected as a complete nest, but broken up by the nestling kite.

\section{Crowned Eagle Stephanoaetus coronatus}

A video camera set up at the nest of a Crowned Eagle pair near White River, showed that the nest was lined with fresh leaves, and weaver nests were added in two successive seasons, in 2019-2020 (Batchelor 2020) and in 2020-2021 (Batchelor 2021). A photo in Batchelor (2021) shows the weaver nest and the photo caption describes it as a Village Weaver nest. The author presumed that the raptors were feeding on chicks in the nests. However, the author's description makes it clear that it is not a case of predation. Although several weaver species nest in association with the Crowned Eagle (Chapin 1932), I have found no records of predation by this raptor on any weaver.
African Fish Eagle Haliaeetus vocifer

There are two separate records of African Fish Eagles using weaver nests as lining. Bangs and Loveridge (1933) recorded water weeds and several globular nests of weaver birds in the lining of an eagle nest (with two fresh eggs) near Ujiji Bay in Tanzania.

Leslie Brown stated that in East Africa, nests of the African Fish Eagle are very often padded with weaver birds' nests or papyrus heads. He also observed an African Fish Eagle taking an occupied weaver nest (that was attached to the eagle's nest) as lining for its own nest (Brown 1980).

\section{Eastern Chanting Goshawk Melierax poliopterus}

In Tsavo National Park East, Kenya, the female of a pair of Eastern Chanting Goshawk brought an unfinished grass nest of a Red-billed Quelea to her nest, after she had been incubating her addled egg for more than six weeks (Smeenk and Smeenk-Enserink 1975). Interestingly, the quelea nest was gradually removed as nest material by Cut-throat Finches Amadina fasciata, who also robbed the goshawks' nest of downy feathers and small twigs.

In the case of the Hamerkop, taking bishop nests may have been accidental (or possibly the bird took reeds with bishop nests deliberately as this would bulk up its own nest). In the other records, it appears that the weaver nests were taken deliberately, and used as nest lining. Raptors and waterbirds are more likely to take a weaver nest where there is a colony near their nest. It is noteworthy that a Crowned Eagle pair took weaver nests in two consecutive seasons.

Weaver nests included green nests, old nests as well as at least one occupied nest (with eggs). Some birds specifically use green plant material as nest lining (Dubiec et al. 2013). The two main hypotheses for passerine birds using green material are the Courtship hypothesis (to attract females to nests), and the Nest Protection and Chemical Defence hypothesis (to deter nest ectoparasites). Dubiec et al. (2013) list, without discussion, a further eight hypotheses for raptors (which could apply to large waterbirds too) using green nest material to: 1 . Enhance nest camouflage, 2. insulate eggs and nestlings, 3. reduce desiccation rate of eggs, 4 . signal nest occupancy, 5 . function in nest sanitation, 6. provide shade for nestlings, 7 . strengthen the nest, and 8 . cover debris (aesthetic function). Since not only green nests were selected, the weaver nests were probably taken as a source of plant material, rather than for any specific benefit relating to fresh material. An advantage of taking a weaver nest is that a larger amount of nest material is obtained at one time. Weaver nests could potentially aid any of the eight functions listed above.

The impact on weavers of having nests taken as nest lining is low, especially as colonial weavers have many empty nests (see also Brown 1980). Rarely, active nests may be taken, causing the loss of the clutch or brood. 
Green weaver nests are expected to have few or no invertebrates, while old nests may harbour some invertebrates (Hicks 1959), many of which are not parasitic and thus are unlikely to have a large impact on raptor or stork nestlings. Old breeding nests of weavers, however, may hold nest mites, e.g. Pellonyssus reedi (Zumpt 1961). While these nest mites show some host specificity, they certainly bite non-related hosts. For example, they are known to bite humans, pers. obs., and are also found on Diederik Cuckoos Chrysococcyx caprius, a common brood parasite of weavers (Lindholm et al. 1998).

In conclusion, there are relatively few published examples of complete weaver nests being taken by large birds but this may be more common than supposed. While weaver nests may simply be a source of plant material, where raptors or waterbirds are nesting near weavers, cases of nest theft should be examined more closely.

\section{References}

Bangs O, Loveridge A. 1933. Reports on the scientific results of an expedition to the southwestern highlands of Tanganyika Territory. III Birds. Bulletin of the Museum of Comparative Zoology, Harvard 75: 143-221. https://www.biodiversitylibrary.org/ page/2806463\#page/174/mode/1up

Batchelor G. 2020. Crowned Eagle news. Hornbill 139: 44-45.

Batchelor G. 2021. Summer 2021 - Crowned Eagle Report. Hornbill 140: 74-76.

Brown L. 1980. The African Fish Eagle. Cape Town : Purnell and Sons.

Chapin JP. 1932. The birds of the Belgian Congo. Part 1. Bulletin of the American Museum of Natural History 65: 1-756. http:// digitallibrary.amnh.org/dspace/handle/2246/491

Cornish L. 2014. The Great Shoebill Hunt - Uganda, with Africa Geographic. Bokmakierie 241: 28-36.
Davenport DL. 1956. Observation of a Hammerkop's nest. Redwing 3(1): 17-18.

Dubiec A, Góüdü I, Mazgajski TD. 2013. Green plant material in avian nests. Avian Biology Research 6(2): 133 -146.

Gush R. 1963. Strange nesting associations. Natal Wildlife 4(4): 13 $-15$.

Gush R. 1993. Interesting nesting associations. Birding in Southern Africa 45: 59.

Hansell M. 2000. Bird nests and construction behaviour. Cambridge: Cambridge University Press.

Harris D, Harris J, Harris C. 1993. Unusual Palmnut Vulture observations. Albatross 316: $23-24$.

Harris D, Harris J, Harris C, Goodwin W. 1994. Observations on the Palmnut Vulture in South Africa. Birding in Southern Africa 46 (3): $73-79$.

Hicks EA. 1959. Check-list and bibliography on the occurrence of insects in birds' nests. Ames, IA: lowa State College Press.

Lindholm AK, Venter GJ, Ueckermann A. 1998. Persistence of passerine ectoparasites on the diederik cuckoo Chrysococcyx caprius. Journal of Zoology 244(1):145 -153. http:// phthiraptera.info/sites/phthiraptera.info/files/40382.pdf

Mainwaring MC, Hartley IR. 2013. The energetic costs of nest building in birds. Avian Biology Research 6: 12 -17.

Millward G. 2009. Close encounters with Woolly-necked Storks. Africa Birds and Birding 14(3): 28 -34.

Moreno J, Bustamante J, Vinuela J. 1995. Nest maintenance and stone theft in the chinstrap penguin (Pygoscelis antarctica). 1. Sex roles and effects on fitness. Polar Biology 15: $533-540$.

Oschadleus HD. 2016. Nesting associations between vultures and weavers. Vulture News 70: 3 -21. https://www.ajol.infol index.php/vulnew/article/view/168867

Smeenk C, Smeenk-Enserink N. 1975. Observations on the Pale Chanting Goshawk Melierax poliopterus, with comparative notes on the Gabar Goshawk Micronisus gabar. Ardea 63: 93 -115 .

Zumpt F (ed). 1961. The arthropod parasites of vertebrates in Africa south of the Sahara (Ethiopian region). Vol 1. (Chelicerata). Johannesburg: South African Institute for Medical Research.

Afrotropical Bird Biology (ABB) is a free, open-access, online journal for articles that describe aspects of the natural and cultural history of birds in the Afrotropical region, including its offshore islands. These include, but are not restricted to, identification features, sounds, distribution and demography, movements, habitats, diseases and parasites, general habits, foraging and food, breeding, interactions with humans, human cultural beliefs and practices as they pertain to birds, moult and biometrics of birds. ABB publishes original contributions focused on presenting information about the natural history of Afrotropical birds. This includes short communications $(<2500$ words, including references) and data papers. All contributions will be reviewed by at least one editor and external, independent referees may also be employed at the discretion of the editors.

All papers are published under the Attribution-NonCommercial CC BY-NC license, which lets others remix, adapt, and build upon your work non-commercially, and although their new works must also acknowledge you and be non-commercial, they don't have to license their derivative works on the same terms. 